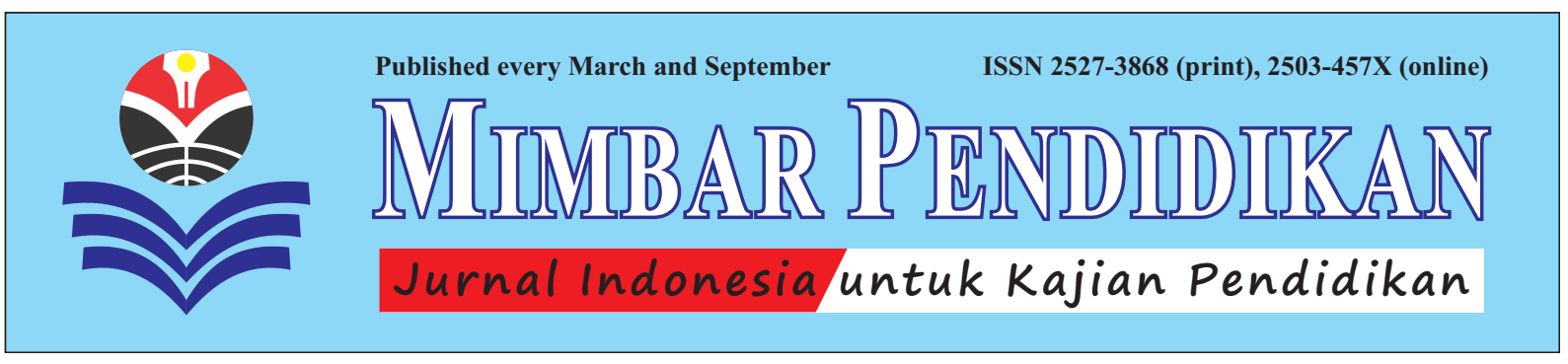

\title{
SUROSO \\ The Policy Planning in Providing Teacher Adequacy for Primary Schools in the Local Government
}

\begin{abstract}
Adequacy of primary school teachers is very important to support education for all. The objective of the research is to analyse and develop a plan for a public policy of teacher adequacy for state primary schools. This research used a descriptive-quantitative approach. Data collection was conducted by using observation and interview. There are six main findings in the research. One of the important things is that the model of planning policy for teacher adequacy based on class can be adopted by other local governments by incorporating two factors: total schools $(S)$ and total classes $(C)$, and using the formula of $n C+2 S$. The planning policy model for teacher adequacy based on students can also be adopted by other local governments by incorporating the total students (S) and student ratio value to teacher (21:1) by using the formula of $S / 21$. Therefore, planners should conduct policy planning analysis for teacher adequacy of state primary schools in the local government by using two perspective analyses simultaneously to ensure teacher adequacy and manage effective and efficient distribution of teachers.

KEY WORD: Teacher Adequacy; Policy Planning; Local Government; Effective and Efficient Distribution; Primary School.
\end{abstract}

ABSTRAKSI: "Perencanaan Kebijakan dalam Penyediaan Kecukupan Guru Sekolah Dasar di Daerah". Kecukupan guru sekolah dasar sangat penting untuk mendukung pendidikan bagi semua. Tujuan penelitian ini adalah untuk menganalisa dan mengembangkan model perencanaan bagi kebijakan kecukupan guru sekolah dasar negeri. Penelitian ini menggunakan pendekatan deskriptif-kuantitatif. Pengumpulan data dilakukan dengan teknik observasi dan wawancara. Ada enam temuan utama dalam penelitian ini. Salah satu yang terpenting adalah bahwa model kebijakan perencanaan kecukupan guru berbasis kelas dapat diadopsi oleh pemerintah daerah lain dengan mengakomodasi 2 faktor: jumlah sekolah (S) dan jumlah kelas (C), dengan menggunakan rumus $n C+2 S$. Model kebijakan perencanaan kecukupan guru berbasis murid dapat juga diadopsi oleh pemerintah daerah lain dengan mengakomodasi faktor jumlah murid (M) dan nilai rasio murid terhadap guru (21:1), dengan menggunakan rumus M/21. Oleh karena itu, perencana sebaiknya melaksanakan analisa kebijakan perencanaan untuk kecukupan guru sekolah dasar negeri di daerah dengan menggunakan dua perspektif analisis tersebut secara simultan untuk menjamin kecukupan guru, dan pengelolaan efektivitas dan efisiensi distribusi guru.

KATA KUNCI: Kecukupan Guru; Perencanaan Kebijakan; Pemerintah Daerah; Efektivitas dan Efisiensi Distribusi; Sekolah Dasar.

About the Author: Dr. Suroso is a Researcher at the Office of Research and Development, Pati Regency, Jalan Panglima Sudirman No.26 Pati, Central Java, Indonesia. For academic interests, the author is able to be contacted via his e-mails at: suroso_peneliti@yahoo.co.id and surosopati321@gmail.com

How to cite this article? Suroso. (2017). "The Policy Planning in Providing Teacher Adequacy for Primary Schools in the Local Government" in MIMBAR PENDIDIKAN: Jurnal Indonesia untuk Kajian Pendidikan, Vol.2(1) March, pp.95-108. Bandung, Indonesia: UPI [Indonesia University of Education] Press, ISSN 2527-3868 (print) and 2503-457X (online).

Chronicle of the article: Accepted (September 29, 2016); Revised (January 29, 2017); and Published (March 30, 2017). 


\section{INTRODUCTION}

Since the framework of EFA (Education For All) was established in 2000, countries have made progress towards the goals. However, too many will still be far from the target (UNESCO, 2014a). Relating to the progress, F.J. Kiprono, M. Nganga \& J. Kanyiri (2015) stated that EFA and MDGs (Millennium Development Goals) came up with significant efforts, primarily through reducing direct costs to parents, to increase primary school enrolment (Kiprono, Nganga \& Kanyiri, 2015).

However, recent analysis shows that the efforts to provide access to a basic education for all children and youth are in peril. Worldwide, there are still 57 million children out of primary school, largely from marginalized populations, such as boys but especially girls, who are affected by armed conflict, extreme poverty, and disability (UNESCO 2013). Globally, 200 million children have not completed primary school, and many who start school leave early, both because of the poor quality of education and also due to household factors such as poverty (UNESCO, 2012).

EFA becomes the priority development globally. There are six goals of EFA: (1) expanding and improving comprehensive early childhood care and education, especially for the most vulnerable and disadvantaged children; (2) ensuring that by 2015 , all children, particularly girls children in difficult circumstances and those belonging to ethnic minorities, have access to and complete free and compulsory primary education of good quality; (3) ensuring that the learning needs of all young people and adults are met through equitable access to appropriate learning and life-skills programmes; (4) achieving a 50 percent improvement in levels of adult literacy by 2015 , especially for women, and equitable access to basic and continuing education for all adults; (5) eliminating gender disparities in primary and secondary education by 2005 , and achieving gender equality in education by 2015 , with a focus on ensuring girls' full and equal access to and achievement in basic education of good quality; and (6) improving all aspects of the quality of education and ensuring excellence of all, so that recognized and measurable learning outcomes are achieved by all, especially in literacy, numeracy, and essential life skills (UNESCO, 2014a and 2014b).

Education for All by 2015: Education International's Response to the Global Monitoring Report 2008, conducted by EI (Education International), the Global Union Federation representing 30 million teachers and education personnel from pre-school to university in 171 countries and territories, stated that there are three main challenges in relation to education quality of EFA or Education For All (EI, 2009).

Firstly, learning outcomes should be monitored. In spite of the weaknesses of comparative tests of achievement, these are widely used as a proxy of what and how much students actually learn in school. At international level, the main assessments show low learning outcomes in much of the world, especially in developing countries. Inequalities are found between and within countries. While in the developed world, learning disparities seem to be attributable to the socio-economic background of pupils and their immigrant status; in developing countries strong disparities favour urban over rural schools. Effective strategies to assess knowledge and skills and demonstrate measurable learning outcomes are needed (EI, 2009).

Secondly, learning environments must be improved. Access to learning resources, first and foremost textbooks, is a key factor. The pupil/textbook ratio is a significant measure of education quality. The SEACMEQ (Southern and Eastern Africa Consortium for Monitoring Educational Quality) survey found that over half the grade 6 pupils in many African countries reported learning 
in classrooms that did not have a single book (Hungi, 2011; and ACER, 2015).

Retention and learning are also hampered, when pupils attend school in dilapidated or overcrowded buildings in noisy or unsafe environments, or, especially, in classrooms that are inadequately supplied or poorly lit and ventilated.

In the SEACMEQ countries, $47 \%$ of school buildings were reported to need major repairs or complete rebuilding; only $13 \%$ were listed in "good" condition. Access to technology is another critical aspect; while it remains inaccessible to most children in the countries that are struggling the most to achieve the EFA goals, in the developed world the recent expansion of ICT (Information and Communication Technology) has facilitated the increased application of various models of distance education and pedagogical innovations (Nzomo \& Makuwa, 2006; Hungi, 2011; and ACER, 2015).

Thirdly, attracting more and better teachers is paramount. The teacher shortage is a major problem, particularly in the developing world, where PTRs (Pupil Teacher Ratios) can reach 40:1 or more (the average for North America and Western Europe is $15: 1)$. In the developing world, this shortage is exacerbated by an even more acute shortage of adequately trained teachers. Exceedingly high PTRs (above 100:1) were found in Afghanistan, Chad, Madagascar, Mozambique, and Nepal; and high ones (above 40:1) in Sub-Saharan Africa (cf WB, 1998; Verwimp, 1999; and Chrispine, 2013).

To succeed the EFA, there are some important factors needed for it; and one of them is an adequate teacher. Dealing with implementation of EFA, the result of global monitoring conducted by UNESCO (United Nations Educational, Scientific, and Cultural Organization), in 2012, shows that EDI (Education Development Index) in Indonesia is at the rate 64 of 120 countries (UNESCO, 2012; and Handini \& Widyaningrum, 2016).
It means that the determinant factors for education quality are not well provided. One of the important determinant factors for education quality is an adequate teacher.

According to I. Syamsuri (2010), teachers have important roles in increasing output of learning and education quality (Syamsuri, 2010:3). In this case, a teacher should have paedagogical competency, because it relates to a learning process (Suparlan, 2006:86). Moreover, the professional teacher should have qualified education and relevant scientific competency (Widiarsa, Marhaeni \& Sutama, 2013:6). Regarding to the teacher competency, UNESCO proposed that there are some important points for increasing teacher competency, including upgrading and sertification (cited in Hamzah, 2009).

To manage teachers in Indonesia, there is a regulation, joint-decision five Ministries. It is the joint-decision of Education Ministry, State Ministry for the Empowerment of State Apparaturs and Bureaucracy Reform, Ministry of Home Affairs, Ministry of Finance, and Ministry of Religious Affairs about Managing and Equity for Civil Servant Teachers (Kemdiknas RI, 2011).

The objective of this study is to analyze and develop a plan for a public policy of the adequate teachers for primary schools. The joint-decision five ministries or SKB (Surat Keputusan Bersama) has been formulated to support previous regulations, such as the law on national education system and government regulation on compulsory learning (Kemdiknas RI, 2003; and Setneg RI, 2008). The objective of the research is to analyze and develop a plan for a public policy of adequate teachers for state primary schools.

"Public policy", accoding to Riant Nugroho (2006), is everything which is done by governments respecting to why they do it and what make the impacts for better living (Nugroho, 2006). To implement the public policy of basic education needs adequate teachers, especially for state schools of basic 
education. Then, "teacher" is a profesional educator who educates, teaches, guides, diracts, trains, and evaluate students at the pre-school formal education, basic education, and middle education (Setneg RI, 2005).

Dealing with managing teachers, especially civil servant teachers for primary schools, the joint-decision five Ministries states that: (1) primary school uses classbased teachers; (2) each class consists of 20-32 students; (3) each class needs 1 classteacher; (4) every primaary school provides teacher of religion and teacher of physical education and health or sport teacher; and (5) the teacher of religion and teacher of physical education and health must teach at least 24 hours per week (Kemdiknas RI, 2011).

Based on the joint-decision five Ministries, there are some criteria and formulas to fulfill the need of teachers for primary school. Based on the regulation, the local government should make a plan in providing adequate teachers for primary school relevant to determined formulas (Kemdiknas RI, 2011). Firstly, it is the formula to calculate the need of class-teacher for primary school. The need of class-teacher is equal to the total of class. Secondly, it is the formula to calculate the need of religion teacher and teacher of physical education and health (sports teacher) for primary school.

The need of teacher is equal to the total teaching hours a week divided by 24 teaching hours for a teacher. Teaching hours a week, namely 24 hours for a teacher, is relevant to the process standard and working load teachers (Kemdiknas RI, 2007; and Kemdiknas RI, 2009).

\section{THE METHOD OF RESEARCH}

This research is conducted in Pati Regency, Central Java, Indonesia. The research uses descriptive-quantitative approach (Mugenda \& Mugenda, 1999; Orodho, 2002; and Ochieng, 2009). The data of the research consist of primary and secondary ones (Kelly, 2005; Moore,
2006; and Bishop, 2007). Data collecting is conducted by using observation and interview (Kelly, 2005; and Schutt, 2006). The data resources consist of documents, field events, and personal resource. The data analyses consist of descriptive analysis and comparative one (O'Sullivan \& Rassel, 1999; and Kelly, 2005).

The formulas for analysing the data, based on SKB (Surat Keputusan Bersama or Joint-Decision) issued by Kemdiknas RI (Kementerian Pendidikan Nasional Republik Indonesia or Ministry of National Education of the Republic of Indonesia), in 2011, are as follows:

The Need Standard of Class-Teachers: $\mathrm{KGK}=\Sigma \mathrm{K} \times 1$ teacher, in which $\mathrm{KGK}=$ Need of Class Teacher; and $\mathrm{K}=$ Class.

The Standard Need of Religion and Sports Teacher: ${ }^{K G A P}=\frac{J T M}{24}=\sum_{i=1}^{r}\left(M P_{i} x \sum_{i} R_{i}\right)$ in which KGAP $=$ Need of Religion Teacher and Teacher of Physical Education and Health; JTM = Total Teaching Hours a Week; MP = Lesson Hours a Week (Religion/Physical Education and Health); and $\Sigma \mathrm{K}=$ Total Class.

Analysis of Adequate Teachers Based Classes for Primary Schools: $\mathrm{ATc}=\mathrm{nC}$ $+2 . \mathrm{S}$, in which $\mathrm{ATc}=$ Adequate Teachers Based on Class; $\mathrm{nC}=$ Total Class; and 2.S = Twice of Total Primary Schools.

Analysis of Adequate Teachers Based Students for Primary Schools: ATm $=\mathrm{m} / \mathrm{rm}$, in which ATm = Adequate Teacher Based on Students; $\mathrm{m}=$ Total Student; and $\mathrm{rm}=$ Ratio Value of Students to Teacher (21:1).

Comparative Analysis of Adequate Teachers for Primary School: $\mathrm{x}^{2}=\sum_{\mathrm{k}=1}^{\mathrm{H}\left(\mathrm{Fo}-\mathrm{Fh}^{2}\right.} \frac{\mathrm{Fh}}{\mathrm{Fh}}$ in which $\mathrm{X}^{2}=$ Value of Chi-Square; Fo = Observed Vaue; and $\mathrm{Fh}=$ Expected Vaue.

\section{THE RESULTS AND DISCUSSION \\ The Analysis Adequate Teachers Based on Classes for Primary Schools.} Previously mentioned in the joint-decision five Ministries that the need of teachers for primary schools or SD (Sekolah Dasar) has 
Table 1:

The Standard of Adequate Teachers Based on Class for Primary School

\begin{tabular}{lclc}
\hline \multicolumn{1}{c}{ Class of Primary School } & Existing Teacher & Meaning & Category \\
\hline 6 Classes & $\mathrm{T} \geq 10$ people & Excessive & $\mathrm{A}$ \\
6 Classes & $8-9$ people & Adequate & $\mathrm{B}$ \\
6 Classes & $\mathrm{T} \leq 7$ people & Shortage & $\mathrm{C}$ \\
\hline
\end{tabular}

Tabel 2:

Adequate Teachers Based on Classes for Primary Schools in Pati Regency

\begin{tabular}{|c|c|c|c|c|c|c|c|}
\hline \multirow[t]{2}{*}{ No } & \multirow{2}{*}{$\begin{array}{c}\text { Districts } \\
\text { (UPT Disdik) }\end{array}$} & \multirow{2}{*}{$\begin{array}{c}\text { Schools } \\
(S D N)\end{array}$} & \multirow{2}{*}{$\begin{array}{c}\text { Teachers } \\
(P N S)\end{array}$} & \multirow{2}{*}{$\begin{array}{c}\text { Classes } \\
\text { (Rombel) }\end{array}$} & \multicolumn{2}{|c|}{ Teacher Need (ATc) } & \multirow[t]{2}{*}{ Categ. } \\
\hline & & & & & $\mathrm{nC}+2 . \mathrm{S}$ & Status & \\
\hline 1 & Sukolilo & 39 & 294 & 256 & 334 & Shortage & -40 \\
\hline 2 & Kayen & 39 & 253 & 234 & 312 & Shortage & -59 \\
\hline 3 & Tambakromo & 32 & 265 & 204 & 268 & Shortage & -3 \\
\hline 4 & Winong & 40 & 307 & 240 & 320 & Shortage & -13 \\
\hline 5 & Pucakwangi & 27 & 177 & 163 & 217 & Shortage & -40 \\
\hline 6 & Jaken & 26 & 153 & 163 & 215 & Shortage & -62 \\
\hline 7 & Batangan & 23 & 153 & 145 & 191 & Shortage & -38 \\
\hline 8 & Juwana & 40 & 321 & 301 & 381 & Shortage & -60 \\
\hline 9 & Jakenan & 27 & 196 & 163 & 217 & Shortage & -21 \\
\hline 10 & Pati & 51 & 403 & 327 & 429 & Shortage & -26 \\
\hline 11 & Gabus & 36 & 256 & 228 & 300 & Shortage & -44 \\
\hline 12 & Margorejo & 29 & 217 & 191 & 249 & Shortage & -32 \\
\hline 13 & Gembong & 23 & 170 & 136 & 182 & Shortage & -12 \\
\hline 14 & Tlogowungu & 30 & 194 & 174 & 234 & Shortage & -40 \\
\hline 15 & Wedarijaksa & 27 & 176 & 176 & 230 & Shortage & -54 \\
\hline 16 & Trangkil & 28 & 188 & 173 & 229 & Shortage & -41 \\
\hline 17 & Margoyoso & 30 & 190 & 197 & 257 & Shortage & -67 \\
\hline 18 & Gunungwungkal & 21 & 150 & 123 & 165 & Shortage & -15 \\
\hline 19 & Cluwak & 28 & 244 & 169 & 225 & Excessive & 19 \\
\hline 20 & Tayu & 28 & 203 & 179 & 235 & Shortage & -32 \\
\hline 21 & Dukuhseti & 25 & 166 & 162 & 212 & Shortage & -46 \\
\hline & Total & 649 & 4,676 & 4,104 & 5,402 & Shortage & -726 \\
\hline
\end{tabular}

the following criteria: (1) primary school uses class-based teachers; (2) each class consists of 20-32 students; (3) each class needs 1 class teacher; (4) every primary school provides teacher of religion and teacher of physical education and health or sport teacher; and (5) the teacher of religion and teacher of physical education and health must teach at least 24 hours per week (Kemdiknas RI, 2011).

Based on the criteria, the standard of adequate teachers for primary school can be analyzed and calculated. Standard of primary school has 6 classes. Each class needs 1 class teacher and the school needs 2 more teacher, namely teacher of religion and teacher of physical education and health (sport teacher); so, the edequate teachers for an primary school with 6 classes is 8 to 9 teachers.

The school may needs only 8 teachers, when the religion teacher is only one person. It means students having relatively similar religion. Otherwise, when the religion of students varies, the need of teacher may become 2 persons, so the edequate teachers for an primary school with 6 classes is 9 
Table 3:

The Criteria for Adequate Teachers Based on Students

\begin{tabular}{|c|c|c|c|c|c|c|}
\hline \multirow{2}{*}{ Standard } & \multirow{2}{*}{ Nominal } & \multicolumn{2}{|c|}{ Students (M) } & \multicolumn{2}{|c|}{ Teacher $(G)$} & \multirow{2}{*}{$\frac{\text { Ratio }}{\text { S:T }}$} \\
\hline & & Min & Max & Min & Max & \\
\hline Classes (Rombel) & 6 & - & - & - & - & - \\
\hline Min Class/Rombel & 20 & 120 & - & 8 & - & 15 \\
\hline Max Class/Rombel & 32 & - & 192 & - & 9 & 21 \\
\hline \multicolumn{7}{|c|}{ Criteria for Evaluation of Adequate Teacher: } \\
\hline Standard of Rombel $S D$ & Ratio S:T & Status & \multicolumn{2}{|c|}{ Category } & & \\
\hline 6 Kelas/Rombel & $\mathrm{R} \leq 14$ & Excessive & $\mathrm{A}$ & & & \\
\hline 6 Kelas/Rombel & $15-21$ & Adequate & B & & & \\
\hline 6 Kelas/Rombel & $\mathrm{R} \geq 22$ & Shortage & $\mathrm{C}$ & & & \\
\hline
\end{tabular}

Note: Rombel is Rombongan Belajar or Class Members. SD is Sekolah Dasar or Primary School.

teachers. The standard of adequate teachers based on class for primary school with 6 classes as shown in table 1 .

The standard of adequate teachers based on class for primary school can be also reformulized as follows: $\mathrm{ATc}=\mathrm{nC}+2 . \mathrm{S}$, in which $\mathrm{ATc}=$ Adequate Teachers Based on Class; $\mathrm{nC}=$ Total Class; and 2.S = Twice of Total Primary Schools.

Pati Regency in Central Java, Indonesia, for instance, has 649 state primary schools; 4,104 classes; and 4,676 teachers. When the adequate teachers based on class uses the formula above, the teacher need is $4,104+(2$ $\mathrm{x} 649)=5,402$. The adequate teachers based on class in Pati Regency are 5,402 teachers. The existing teachers are 4,676 persons and the need or adequate teachers are 5,402 persons, so the shortage of teachers are -726 persons.

The existing teachers and adequate standard teachers for primary schools in Pati Regency are depicted in the table 2.

Most districts have shortage teachers for primary schools except one, Cluwak District has excessive teachers for primary schools (19 teachers). The shortage of teachers based on class for primary schools are 726 persons in Pati Regency, Central Java, Indonesia. However, policy planning should be having more analyses, such as the analysis of the adequate teachers based on students.
The Analysis Adequate Teachers Based on Students for Primary Schools. Policy planning in providing adequate teachers for primary school should consider more feasibility in term of efectiveness and efficiency (Stockey \& Zeckhauser, 1978; Haddad, 1995; and Fullan \& Langworthy, 2013). In facts, some primary schools have less students (under standard) in the area study. An example, SDN (Sekolah Dasar Negeri or State Primary School) Prawoto 03 in Sukolilo District has 6 classes and 53 students, so the average class is only 8 or 9 pupils. Even, SDN Bremi 03 in Gembong District has only 31 students in 5 classes, so the average class is only 6 pupils.

The classes with less students can be problems in effectiveness and efficiency for teacher management. That is why policy planning should be having more analyses, such as analysis of the adequate teachers based on student. It is useful to improve the effectiveness and efficiency in the teacher management ( $c f$ Peterson, 2000; Danielson, 2001; and Avalos \& Assael, 2006).

The analysis of adequate teachers based on students should be also relevant to the joint-decision five Ministries. It states each class consists of 20 to 32 students (Kemdiknas RI, 2011). The standard class for a primary school has 6 classes, so the minimum students are 120 pupils and the 
Tabel 4:

Adequate Teachers Based on Students for Primary Schools in Pati Regency

\begin{tabular}{|c|c|c|c|c|c|c|c|}
\hline \multirow{2}{*}{ No } & \multirow{2}{*}{$\begin{array}{c}\text { District } \\
\text { (UPT Disdik) }\end{array}$} & \multirow{2}{*}{$\frac{\text { Schools }}{\text { (SDN) }}$} & \multirow{2}{*}{$\begin{array}{c}\text { Teachers } \\
\text { (PNS) }\end{array}$} & \multirow{2}{*}{ Students } & \multicolumn{2}{|c|}{ Teacher Need } & \multirow{2}{*}{ Categ. } \\
\hline & & & & & $(\mathrm{S} / 21)$ & Status & \\
\hline 1 & Sukolilo & 39 & 294 & 5,832 & 278 & Excessive & 16 \\
\hline 2 & Kayen & 39 & 253 & 4,944 & 235 & Excessive & 18 \\
\hline 3 & Tambakromo & 32 & 265 & 4,328 & 206 & Excessive & 59 \\
\hline 4 & Winong & 40 & 307 & 4,334 & 206 & Excessive & 101 \\
\hline 5 & Pucakwangi & 27 & 177 & 2,652 & 126 & Excessive & 51 \\
\hline 6 & Jaken & 26 & 153 & 3,171 & 151 & Adequate & 2 \\
\hline 7 & Batangan & 23 & 153 & 2,927 & 139 & Excessive & 14 \\
\hline 8 & Juwana & 40 & 321 & 7,606 & 362 & Shortage & -41 \\
\hline 9 & Jakenan & 27 & 196 & 3,110 & 148 & Excessive & 48 \\
\hline 10 & Pati & 51 & 403 & 8,874 & 423 & Shortage & -20 \\
\hline 11 & Gabus & 36 & 256 & 4,804 & 229 & Excessive & 27 \\
\hline 12 & Margorejo & 29 & 217 & 4,303 & 205 & Excessive & 12 \\
\hline 13 & Gembong & 23 & 170 & 2,381 & 113 & Excessive & 57 \\
\hline 14 & Tlogowungu & 30 & 194 & 2,917 & 139 & Excessive & 55 \\
\hline 15 & Wedarijaksa & 27 & 176 & 4,673 & 223 & Shortage & -47 \\
\hline 16 & Trangkil & 28 & 188 & 4,628 & 220 & Shortage & -32 \\
\hline 17 & Margoyoso & 30 & 190 & 4,156 & 198 & Shortage & -8 \\
\hline 18 & Gunungwungkal & 21 & 150 & 1,821 & 87 & Excessive & 63 \\
\hline 19 & Cluwak & 28 & 244 & 2,372 & 113 & Excessive & 131 \\
\hline 20 & Tayu & 28 & 203 & 3,724 & 177 & Excessive & 26 \\
\hline \multirow[t]{2}{*}{21} & Dukuhseti & 25 & 166 & 2,799 & 133 & Excessive & 33 \\
\hline & & 649 & 4,676 & 86,356 & 4,112 & Excessive & 564 \\
\hline
\end{tabular}

Note: UPT Disdik = Unit Pelaksana Teknis Dinas Pendidikan (Techical Execution Unit of Education Institution); $\mathrm{SDN}=$ Sekolah Dasar Negeri (State Primary School); and PNS = Pegawai Negeri Sipil (Civil Servant).

maximum students are 192. The adequate teachers are 8 to 9 persons (see previous description).

Based on the values, the minimum ratio of student-teacher is $15: 1$ deriving from $120 / 8$; and the the maximum ratio of student-teacher is $21: 1$ deriving from 192/9. Therefore, the criteria for adequate teachers based on students are as shown in table 3 .

Relating to adequate teachers based on students, Pati Regency in Central Java, Indonesia has 649 state primary schools; 4,676 teachers; and 86,356 students. When the adequate teachers based on student, the need of teachers becomes 86,356/21 $=4,112$. The adequate teachers based on student in Pati Regency are 4,112 teachers. The existing teachers are 4,676 persons and the adequate teachers are 4,112 persons, so the excessive teachers are 564 persons.

Sukolilo District, for instance, has 39 state primary schools; 294 teachers; and 5,832 students. When the adequate teachers based on student, the need of teachers becomes $5,832 / 21=278$. The adequate teachers based on student in the district are 278 teachers. The existing teachers are 294 persons and the adequate teachers are 278 persons, so the excessive teachers are 16 persons.

In the context of adequate teachers based on students, most districts in Pati Regency has excessive teachers. The existing teachers and adequate teachers based on student for primary schools are depicted in the table 4 .

Most districts in Pati Regency, Central Java, Indonesia have "excessive" teachers. Only few districts have "shortage" teachers. This finding shows that classes or Rombel 
Table 5:

Matrix of Adequate Teachers

\begin{tabular}{lcc}
\hline \multicolumn{1}{c}{ The Need of Teacher for Primary School } & Analyzed Values & Expected Values \\
\hline Adequate teachers based on class & 5,402 & 4,757 \\
Adequate teachers based on student & 4,112 & 4,757 \\
\hline Total & $\mathbf{9 , 5 1 4}$ & $\mathbf{9 , 5 1 4}$ \\
\hline
\end{tabular}

Table 6:

The Need of Teachers

\begin{tabular}{lccccc}
\multicolumn{1}{c}{ The need of teacher } & Fo & Fh & Fo - Fh & $(\text { Fo }- \text { Fh })^{\mathbf{2}}$ & $\left((\mathbf{F o}-\mathbf{F h})^{\mathbf{2}}\right) /$ Fh \\
\hline Teachers based on class & 5,402 & 4,757 & 645 & 416,025 & 87.46 \\
Teachers based on student & 4,112 & 4,757 & -645 & 416,025 & 87.46 \\
\hline Total & $\mathbf{9 , 5 1 4}$ & $\mathbf{9 , 5 1 4}$ & & & $\mathbf{1 7 4 . 9 1}$ \\
\hline
\end{tabular}

(Rombongan Belajar) of primary school are in general under standard (less than 28 pupils). The needs between adequate teachers based on class and adequate teachers based on student for primary school are significantly different, if the needs are compared.

\section{The Comparative Analyses of Adequate} Teachers for Primary Schools. Pati Regency in Central Java, Indonesia has 649 state primary schools; 4,104 classes; 4,676 teachers; and 86,356 students in 2015. The adequate teachers based on class for primary school are 5,402 persons; so the shortage of teachers based on class for primary schools are 726 persons. On the other hand, the adequate teachers based on student for primary school are 4,112 persons; so, the excessive teachers are 564 persons.

The different needs between adequate teachers based on class and adequate teachers based on student for primary school are 1,290 teachers. The values can be arranged in the matrix as shown in table 5 .

Based on the values in table 5, Chi-square $\left(\mathrm{X}^{2}\right)$ can be counted by using the matrix in table 6 .

The values of Chi-square $\left(\mathrm{X}^{2}\right)$ is 174.91 . On the other hand, the table-value of Chisquare $\left(\mathrm{X}^{2}\right)$ for dk 1 (2 category -1$)$ and significant error $5 \%$ is 3.841 . The counting value of Chi-square $\left(\mathrm{X}^{2}\right) 174.91$ is more than the table-value of Chi-square $\left(\mathrm{X}^{2}\right), 3.841$. It means there is a significant disparity between adequate teachers based on class and adequate teachers based on student for primary school. It means also that classes or Rombel (Rombongan Belajar) of primary schools are in general under standard (less than 28 pupils). Therefore, practice policy in providing adequate teachers should consider the existing classes and students for improving effectiveness and efficiency of teacher distribution ( $c f$ Barnett, McCormick \& Conners, 2001; Bredeson, 2003; and Mulford, 2003).

\section{The Public Policy in Managing} Distribution for Adequate Teachers. Public policy in managing distribution for adequate teachers should consider the existing classes and students (Stockey \& Zeckhauser, 1978; Haddad, 1995; and Fullan \& Langworthy, 2013). This is very important to ensure adequate teachers and managing effective and efficient distribution of adequate teachers. Some state primary schools may have shortage of teachers (C) in the perspective of adequate teachers based on class; and, at the same time, the schools may have exessive teachers (A) based on students. It means the total number of students is under standard (less than 28 students per class). 
Tabel 7:

The Public Policy in Managing Distribution for Adequate Teachers

\begin{tabular}{|c|c|c|c|c|}
\hline \multirow{2}{*}{ No } & \multicolumn{2}{|c|}{ Existing Teachers Per School } & \multirow{2}{*}{$\begin{array}{c}\text { Classes/Rombel } \\
\text { (R Standard) }\end{array}$} & \multirow{2}{*}{$\begin{array}{c}\text { Policy Priority of Teachers } \\
\text { (Employed to School) }\end{array}$} \\
\hline & Based on Class & Based on Student & & \\
\hline 1 & C (Shortage) & $\mathrm{C}$ (Shortage) & $\mathrm{R}=6$ & First priority for adding teachers. \\
\hline 2 & C (Shortage) & C (Shortage) & $\mathrm{R}>6$ & Control in enrollment as standard. \\
\hline 3 & C (Shortage) & B (Adequate) & $R=6$ & Second priority for adding teachers. \\
\hline 4 & C (Shortage) & A (Exessive) & $\mathrm{R} \leq 6$ & Merging among the schools. \\
\hline 5 & B (Adequate) & $\mathrm{A} / \mathrm{B} / \mathrm{C}$ & $\mathrm{R} \leq 6$ & Control to sustain the schools. \\
\hline 6 & A (Exessive) & A (Exessive) & $R \geq 6$ & First priority for reducing teachers. \\
\hline 7 & A (Exessive) & B (Adequate) & $R \geq 6$ & Second priority for reducing teachers. \\
\hline 8 & A (Exessive) & $\mathrm{C}$ (Shortage) & $R \geq 6$ & Third priority for reducing teachers. \\
\hline
\end{tabular}

That is a common phenomena for some schools in the study area.

Previously mentioned that Pati Regency in Central Java, Indonesia has 649 state primary schools; 4,104 classes; 4,676 teachers; and 86,356 students. The adequate teachers based on class for primary school are 5,402 persons; so the shortage of teachers based on class for primary schools are 726 persons. On the other hand, the adequate teachers based on student for primary school are 4,112 persons; so the excessive teachers are 564 persons. It indicates that many schools have students under standard (less than 28 students per class).

In practice, when primary school $\mathrm{Y}$, for instance, has existing teachers less than the need of teachers based on class, it means the existing teachers in primary school $\mathrm{Y}$ is "shortage" (C). At the same time, when primary school $\mathrm{Y}$ has existing teachers less than the need of teachers based on student, it means the existing teachers in primary school $\mathrm{Y}$ is "shortage" (C). If primary school $\mathrm{Y}$ has classes as normative standard (6 classes), this school should be added with a new or new teacher(s). Otherwise the primary school Y has classes more than normative standard (7 classes or more), this school should be controlled in enrollment of new students annually.

The public policy for adequate teachers should be conducted carefully to ensure adequate teachers, and managing effective and efficient distribution of teachers (Stockey \& Zeckhauser, 1978; Haddad, 1995; and Fullan \& Langworthy, 2013). In general, the public policy in managing distribution for adequate teacher is depicted in the table 7.

\section{The Adoption of the Policy Model} in Distribution Planning of Adequate Teachers. The model of policy planning for adequate teachers of elementary schools can be adopted by other local governments (Ibe-Bassey, 1987; Jehl et al., 2001; and Torma, 2004). ${ }^{1}$ The analysis of adequate teachers based on the existing classes should incorporate two basic factors, namely: total schools, especially state elementary schools; and total classes (Ehrenberg et al., 2001; and Hanushek, 2003).

The proximate for adequate teachers of elementary schools can be calculated by using the formula $\mathrm{nC}$ (total class referring one class one teacher), then added 2.S (referring each elementary school need 1 teacher of religion and 1 teacher of sport education). The local governments can adopt the model of the policy planning for adequate teacher of elementary school for their own local government (Ibe-Bassey, 1987; Jehl et al., 2001; Torma, 2004; and Kusumoto, 2008).

Local government of Pati Regency in Central Java, Indonesia, for instance, has

${ }^{1}$ See also, for example, "Local Governments and Schools: A Community Oriented Approach". Available online at: file:///C:/Users/acer/Downloads/\%7BD0E0026C7C49-447E-ADF0-F7C5E52A9D16\%7D.pdf [accessed in Pati, Indonesia: January 15, 2016]. 
Tabel 8:

The Policy Planning Adoption for Adequate Teachers Based on Classes

\begin{tabular}{clccc}
\hline No & Local Government & State Schools (S) & Classes (nC) & $\begin{array}{c}\text { The Need of Teachers } \\
(\mathbf{n C}+\mathbf{2 . S})\end{array}$ \\
\hline 1 & Pati Regency & 649 & 4,104 & $4,104+(2 \times 649)=5,402$ \\
2 & Regency A & 650 & 4,200 & $4,200+(2 \times 650)=5,500$ \\
3 & Regency B & 350 & 2,500 & $2,500+(2 \times 350)=3,200$ \\
\hline
\end{tabular}

Tabel 9.

The Policy Planning Adoption for Adequate Teachers Based on Students

\begin{tabular}{clccc}
\hline No & Local Government & Students (S) & Ratio Student to Teacher & The Need of Teachers (s/21) \\
\hline 1 & Pati Regency & 86,356 & 21 & 4,112 \\
2 & Regency A & 89,000 & 21 & 4,238 \\
3 & Regency B & 63,000 & 21 & 3,000 \\
\hline
\end{tabular}

649 state elementary schools (S) and the total learning groups consisting 4,104 classes $(\mathrm{nC})$, so the adequate teachers of elementary schools in the local government are 4,104 $+(2 \times 649)=5,402$ teachers. Other local government, assumption Regency A has 650 state elementary schools (S) and the total learning groups consisting 4,200 classes (nC), so the adequate teachers of elementary schools in the local government A are 4,200 $+(2 \times 650)=5,500$ teachers. The other local government, assumption Regency B has 350 state elementary schools (S) and the total learning groups consisting 2,500 classes (nC), so the adequate teachers of elementary schools in the local government B is 2,500+ $(2 \times 350)=3,200$ teachers.

This is the way to determine the proximate for adequate teachers based on class of elementary school/primary school, which can be adopted by other local government; and it is shown in the table 8.

Policy planning in providing adequate teachers should be analyzed by using another perspective, namely adequate teachers based students (Griffin, Jones \& Kilgore, 2006; Hagger \& McIntyre, 2006; and Kosnik \& Beck, 2009). It is useful to improve the effectiveness and efficiency in the teacher management. The analysis of adequate teachers based on students should be considered two factors, namely: students (S) and normative standard of learner group. According to the joint-decision five Ministries, it states that a primary school has 6 classes and each class consisting 20 to 32 students, so the minimum students are 120 pupils in a primary/elementary school; and the maximum students are 192 pupils (Kemdiknas RI, 2011).

The adequate teachers are 8 to 9 persons (see previous description). Based on the values, the minimum ratio of student-teacher is $15: 1$ deriving from $120 / 8$; and the maximum ratio of student-teacher is $21: 1$ deriving from $192 / 9$. Therefore, the adequate teachers based on student can be analyzed by using fromula $(\mathrm{m} / 21)$. It means that each 21 students need 1 teacher referring the ratio $21: 1$.

Local government of Pati Regency in Central Java, Indonesia, for instance, has 649 state elementary schools with the total students 86,356 pupils (S), so the adequate teachers based on students of elementary schools in the local government are $86,356 / 21=4,112$ teachers. Other local government, assumption Regency A, has 650 state elementary schools with the total students 89,000 pupils (S), so the adequate teachers based on students of elementary 
schools in the local government $\mathrm{A}$ is $89,000 / 21=4,238$ teachers. The other local government, assumption Regency $\mathrm{B}$, has 350 state elementary schools with the total students 63,000 pupils (S), so the adequate teachers based on students of elementary schools in the local government B is $63,000 / 21=3,000$ teachers. See table 9 .

This is the way to determine the proximate for adequate teachers based on student of elementary school/primary school. This model can be adopted by other local governments in Indonesia.

\section{CONCLUSION $^{2}$}

There are some main findings in this study. There are two eligible models for analyzing adequate teachers of primary schools, namely: adequate teachers based on learning groups (class) and adequate teachers based on students. The adequate teachers based on class in Pati Regency, Central Java, Indonesia, in which has 649 state primary schools; 4,104 classes; and 4,676 teachers are shortage of 726 teachers, because the adequate teachers based on class are 4,104 $+(2 \times 649)=5,402$. The existing teachers are 4,676 persons and the adequate teachers based on classes are 5,402 persons, so the shortage of teachers are -726 persons.

The adequate teachers based on students in Pati Regency, in which has 649 state primary schools; 4,676 teachers; and 86,356 students are excessive 564 teachers, because the needs are 86,356/21 $=4,112$ teachers. The existing teachers are 4,676 persons and the adequate teachers based on students are

\footnotetext{
${ }^{2}$ Acknowledgments: I appreciate to the related parties in Pati Regency, Central Java, Indonesia. Firstly, they are the chief and the staff of BAPPEDA (Badan Perencanaan Pembangunan Daerah or Regional Development Planning Body), who provided the funding to conduct the study. Secondly, they are the chief and the staff at the Department of Education, who helped to provide data of the study. Thirdly, they are the chief and the staff in the Office of Research and Development and also other parties who have helped to conduct the research. However, all contents and interpretations related to this article are become the responsibility of my own self academically.
}

4,112 persons, so the excessive teachers are 564 people. Comparative analysis between adequate teachers based on classes and adequate teachers based on students has significant disparity, in which the counting value of Chi-square $\left(\mathrm{X}^{2}\right) 174.91$ is more than the table value of Chi-square $\left(\mathrm{X}^{2}\right) 3.841$.

The model of policy planning for adequate teachers based on clasess of elementary schools can be adopted by other local governments, in which the adoptation should incorporate two basic factors, namely: total schools (S), especially state elementary schools and total class (C) by using a formula $\mathrm{nC}$ (Total Classes), then added 2S (referring each elementary school need 1 religion teacher and 1 sport education teacher). The model of policy planning for adequate teachers based on students of elementary schools can be adopted by other local governments, in which the adoptation should consider the total number of students (S) then divided by 21 (referring ratio students to teacher 21:1).

The local planner in the local government should be analyzed the adequate teachers carefully. The planner should conduct the policy planning analyses for adequate teachers of state primary schools in the local government by using two perspectives' analyses simultanously. Those analyses are simultanously important to ensure adequate teachers, and managing effective and efficient distribution of teachers. ${ }^{3}$

\section{References}

\section{ACER [Australian Council for Educational Research]. (2015). "The Southern and Eastern Africa Consortium for Monitoring}

\footnotetext{
${ }^{3}$ Statement: I guarantee that the paper is an original work. It is not a product of plagiarism, and not also be submitted and published by other scholarly journal. If the paper has been received, I will not withdrawal this paper from the MIMBAR PENDIDIKAN journal. I certify that all my statements are true and correct.
} 
Educational Quality". Available online at: http://research.acer.edu.au/cgi/viewcontent. cgi? article $=1007 \&$ context $=$ assessgems [accessed in Pati, Indonesia: March 2, 2016].

Avalos, B. \& J. Assael. (2006). "Moving from Resistance to Agreement: The Case of the Chilean Teacher Performance Evaluation" in International Journal of Educational Research, Vol.45, No.4-5, pp.254-266.

Barnett, K., P. McCormick \& R. Conners. (2001). "Transformational Leadership in Schools" in Journal of Educational Administration, 39(1), pp.24-46.

Bishop, L. (2007). "A Reflexive Account of Reusing Qualitative Data: Beyond Primary/Secondary Dualism" in Sociological Research Online: Special Section on Reusing Qualitative Data, 12(3), May. Available online also at: http://www.socresonline. org.uk/12/3/2.html [accessed in Pati, Indonesia: January 15,2016$]$.

Bredeson, P. (2003). Designs for Learning: A New Architecture for Professional Development in Schools. Thousand Oaks, CA: Corwin Press.

Chrispine, Ochieng. (2013). "Classroom-Based Factors Influencing Teaching and Learning in Public Primary Schools in Ukwala Division of Siaya County, Kenya". A Research Project Submitted in Partial Fulfillment of the Requirements for the Degree of Master of Education in Curriculum Studies at the University of Nairobi, Kenya. Available online also at: http:// erepository.uonbi.ac.ke/bitstream/handle [accessed in Pati, Indonesia: March 2, 2016].

Danielson, C. (2001). "New Trends in Teacher Evaluation" in Educational Leadership, Vol.58, No.5, pp.12-15.

Ehrenberg, Ronald G. et al. (2001). "Class Size and Student Achievement" in Psychological Science in the Public Interest, Vol.2(1). Available online also at: https://www.psychologicalscience.org/journals/ pspi/pdf/pspi2 1.pdf?origin $=\mathrm{p}$ [accessed in Pati, Indonesia: January 15, 2016].

EI [Education International]. (2009). Education for All by 2015: Education International's Response to the Global Monitoring Report 2008. Brussels: Education International.

Fullan, M. \& M. Langworthy. (2013). Towards a New End: New Pedagogies for Deep Learning. Seattle: Creative Commons.

Griffin, C.C., H.A. Jones \& K.L. Kilgore. (2006). "A Qualitative Study of Student Teachers' Experiences with Collaborative Problem Solving" in Teacher Education and Special Education, 29(1), pp.44-55

Haddad, Wadi D. (1995). Education Policy-Planning Process: An Applied Framework. Paris: UNESCO [United Nations Educational, Scientific, and
Cultural Organization]. Available online also at: http://www.unesco.org/education/pdf/11 200.pdf [accessed in Pati, Indonesia: March 2, 2016].

Hagger, H. \& D. McIntyre. (2006). Learning Teaching from Teachers. Maidenhead: Open University Press.

Hamzah, Nur. (2009). "Pendidikan dan Tenaga Kependidikan" dalam Jurnal MEDTEK, Vol.1, No.2, hlm.1-10.

Handini, O. \& R. Widyaningrum. (2016). “Kontribusi Pedagogik dan Kompetensi Profesional Guru terhadap Manajemen Kelas" dalam Jurnal Profesi Pendidik, Vol.3, No.1, hlm.36-43.

Hanushek, E.A. (2003). "The Failure if Input-Based Schooling Policies" in Economic Journal, Vol.113, No.48, 5 February, pp.64-98.

Hungi, N. (2011). "Characteristics of Grade 6 Pupils: Their Homes and Learning Environments". Paper presented in the SEACMEQ (Southern and Eastern Africa Consortium for Monitoring Educational Quality) in Paris, France.

Ibe-Bassey, G.S. (1987). "Selecting Instructional Materials within the Process of Planning Lessons" in Journal of Research in Curriculum, Vol.5, No.1, pp.45-56.

Jehl, Jeanne et al. (2001). Education and Community Building: Connecting Two Worlds. Washington, D.C.: Institute for Educational Leadership.

Kelly, M. (2005). Primary and Secondary Data. New York: McKinnon Secondary College.

Kemdiknas RI [Kementerian Pendidikan Nasional Republik Indonesia]. (2003). Undang-Undang Nomor 20 Tahun 2003 tentang Sistem Pendidikan Nasional. Jakarta: Penerbit Sinar Grafika.

Kemdiknas RI [Kementerian Pendidikan Nasional Republik Indonesia]. (2007). Peraturan Menteri Pendidikan Nasional Nomor 41 Tahun 2007 tentang Standar Proses untuk Satuan Pendidikan Dasar dan Menengah. Jakarta: Setjen Kemdiknas RI [Sekretariat Jenderal Kementerian Pendidikan Nasional Republik Indonesia].

Kemdiknas RI [Kementerian Pendidikan Nasional Republik Indonesia]. (2009). Peraturan Menteri Pendidikan Nasional Nomor 39 Tahun 2009 tentang Pemenuhan Beban Kerja Guru dan Pengawas Satuan Pendidikan. Jakarta: Biro Hukum dan Organisasi, Kemdiknas RI.

Kemdiknas RI [Kementerian Pendidikan Nasional Republik Indonesia]. (2011). Surat Keputusan Bersama (SKB) oleh Lima Menteri, yaitu Menteri Pendidikan Nasional, Menteri Negara Pendayagunaan Aparatur Negara dan Reformasi Birokrasi, Menteri Dalam Negeri, Menteri Keuangan, dan Menteri Agama dengan Nomor: 05/x/pb/2011,SPB/03/M.PAN-RB/10/2011, 48 Tahun 2011, 158/PMK/01/2011, 11 Tahun 2011, Tahun 2011 tentang Penataan dan Pemerataan 
Guru Pegawai Negeri Sipil. Jakarta: Setjen Kemdiknas RI [Sekretariat Jenderal Kementerian Pendidikan Nasional Republik Indonesia].

Kiprono, F.J., M. Nganga \& J. Kanyiri. (2015). “An Assessment of School Management Commitees' Capacity in the Implementation of FPE Funds in the Public Primary Schools: A Survey of Eldoret East District, Kenya" in International Journal of Education and Research, Vol.3, No.1, pp.243.

Kosnik, C. \& C. Beck. (2009). Priorities in Teacher Education: The 7 Key Elements of Pre-Service Preparation. Oxford: Routledge.

Kusumoto, Yoko. (2008). "Needs Analysis: Developing a Teacher Training Program for Elementary School Homeroom Teachers in Japan" in Second Language Studies, 26(2), Spring, pp.144. Available online also at: http://www.hawaii. edu/sls/wp-content/uploads/2014/09/Kusumoto.pdf [accessed in Pati, Indonesia: January 15, 2016].

"Local Governments and Schools: A Community Oriented Approach". Available online at: file://C:/ Users/acer/Downloads/\%7BD0E0026C-7C49447E-ADF0-F7C5E52A9D16\%7D.pdf [accessed in Pati, Indonesia: January 15, 2016].

Moore, N. (2006). "The Contexts of Context: Broadening Perspectives in the (Re)Use of Qualitative Data" in Sociological Research Online: Special Section on Reusing Qualitative Data, 12(3). Available online also at: http://erdt. plymouth.ac.uk/mionline/public html/viewarticle. php?id=27\&layout $=$ html [accessed in Pati, Indonesia: January 15, 2016].

Mugenda, O. \& A. Mugenda. (1999). Research Methods: Quantitative and Qualitative Approaches. Nairobi: Acts Press.

Mulford, Bill. (2003). "School Leaders: Changing Roles and Impact on Teacher and School Effectiveness". A paper commissioned by the Education and Training Policy Division, OECD, for the Activity Attracting, Developing and Retaining Effective Teachers. Available online also at: https://www.oecd.org/edu/school/2635399.pdf [accessed in Pati, Indonesia: January 15, 2016].

Nzomo, J. \& D. Makuwa. (2006). "How Can Countries Move from Cross-National Research Results to Dissemination and then to Policy Reform?: Case Studies from Kenya and Namibia" in K. Ross \& I.J. Genevois [eds]. Cross-National Studies of the Quality of Education. Paris: UNESCO [United Nations for Educational, Scientific and Cultural Organization], pp.213-228.

Nugroho, Riant. (2006). Kebijakan Publik untuk Negara-negara Berkembang. Jakarta: PT Gramedia Pustaka Utama.

Ochieng, P.A. (2009). “An Analysis of the Strengths and Limitation of Qualitative and Quantitative
Research Paradigms" in Problems of Education in the 21st Century, 13, pp.13-18.

Orodho, J.A. (2002). Techniques of Writing Research Proposals and Reports in Education and Social Sciences. Nairobi: Masola Publishers.

O’Sullivan, E. \& G.R. Rassel. (1999). Research Methods for Public Administrators. London: Longman, 3rd edition.

Peterson, K. (2000). Teacher Evaluation: A Comprehensive Guide to New Directions and Practices. Thousand Oaks, CA: Corwin Press, 2nd edition.

Schutt, R. (2006). Investigating the Social World. New York: Sage Publications.

Setneg RI [Sekretariat Negara Republik Indonesia]. (2005). Undang-Undang Nomor 14 Tahun 2005 tentang Guru dan Dosen. Jakarta: Sekretariat Negara Republik Indonesia.

Setneg RI [Sekretariat Negara Republik Indonesia]. (2008). Peraturan Pemerintah Nomor 47 Tahun 2008 tentang Wajib Belajar. Jakarta: Sekretariat Negara Republik Indonesia.

Stockey, E. \& R. Zeckhauser. (1978). A Primer for Policy Analysis. New York: W.W. Norton and Company.

Suparlan. (2006). Guru sebagai Profesi. Yogyakarta: Hikayat Publishing.

Syamsuri, I. (2010). "Peningkatan Kompetensi Guru untuk Meningkatkan Minat Siswa pada Bidang MIPA". Makalah dalam Lokakarya MIPA [Matematika dan Ilmu Pengetahuan Alam]-net di Institut Pertanian Bogor, pada tanggal 26-27 Juli.

Torma, Tim. (2004). "Back to School for Planners" in Planning Commissioners Journal, Issue of October. Available online also at: http://www. plannersweb.com/schools.html [accessed in Pati, Indonesia: January 15, 2016].

UNESCO [United Nations for Educational, Scientific and Cultural Organization]. (2012). Untangling Aid in National Education Budgets: EFA Global Monitoring Report Background Paper. Paris: The United Nations Educational, Scientific, and Cultural Organization.

UNESCO [United Nations for Educational, Scientific and Cultural Organization]. (2013). Schooling of Millions of Children Jeopardized by Reductions in Aid: Global Monitoring Report Policy, Paper 9. Paris: The United Nations Educational, Scientific, and Cultural Organization.

UNESCO [United Nations for Educational, Scientific and Cultural Organization]. (2014a). Education for All: Global Monitoring Report 2013. Paris: The United Nations Educational, Scientific, and Cultural Organization.

UNESCO [United Nations for Educational, Scientific 
and Cultural Organization]. (2014b). Education Strategy, 2014-2021. Paris: United Nations for Educational, Scientific and Cultural Organization. Verwimp, P. (1999). "Measuring the Quality of Education at Two Levels: A Case Study of Primary Schools in Rural Ethiopia" in International Review of Education, 45(2), pp.167-196.
WB [World Bank]. (1998). Education in Sub-Saharan Africa: Policies of Readjustment, Revitalization, and Expansion. Washington, D.C.: World Bank. Widiarsa, I.G.P., A. Marhaeni \& I.M. Sutama. (2013). "Kontribusi Kompetensi Paedagogik dan Kompetensi Profesional terhadap Manajemen Kelas" dalam E-journal Pasca UNDIKSA, Vol.3, No.1, hlm.1-11. 